\title{
Mechanisms of Iron Uptake from Ferric Phosphate Nanoparticles in Human Intestinal Caco-2 Cells
}

\author{
Antonio Perfecto ${ }^{1}$, Christine Elgy ${ }^{2}$, Eugenia Valsami-Jones ${ }^{2}$, Paul Sharp ${ }^{3}$, Florentine Hilty ${ }^{4}$ \\ and Susan Fairweather-Tait ${ }^{1, *}$ \\ 1 Norwich Medical School, University of East Anglia, Norwich, Norfolk NR4 7UQ, UK; a.perfecto@uea.ac.uk \\ 2 School of Geography, Earth and Environmental Sciences, University of Birmingham, Edgbaston, \\ Birmingham B15 2TT, UK; c.n.elgy@bham.ac.uk (C.E.); e.valsamijones@bham.ac.uk (E.V.-J.) \\ 3 Diabetes and Nutritional Sciences Division, King's College London, London SE1 9NH, UK; \\ paul.a.sharp@kcl.ac.uk \\ 4 Institute of Food, Nutrition, and Health, ETH, Schmelzbergstrasse 9, 8092 Zürich, Switzerland; \\ florentine.hilty@gmail.com \\ * Correspondence: s.fairweather-tait@uea.ac.uk; Tel.: +44-(0)1603-591-304
}

Received: 27 January 2017; Accepted: 30 March 2017; Published: 4 April 2017

\begin{abstract}
Food fortification programs to reduce iron deficiency anemia require bioavailable forms of iron that do not cause adverse organoleptic effects. Rodent studies show that nano-sized ferric phosphate $\left(\mathrm{NP}-\mathrm{FePO}_{4}\right)$ is as bioavailable as ferrous sulfate, but there is controversy over the mechanism of absorption. We undertook in vitro studies to examine this using a Caco-2 cell model and simulated gastrointestinal (GI) digestion. Supernatant iron concentrations increased inversely with $\mathrm{pH}$, and iron uptake into Caco-2 cells was 2-3 fold higher when $\mathrm{NP}-\mathrm{FePO}_{4}$ was digested at $\mathrm{pH} 1$ compared to $\mathrm{pH} 2$. The size and distribution of $\mathrm{NP}-\mathrm{FePO}_{4}$ particles during GI digestion was examined using transmission electron microscopy. The $\mathrm{d} 50$ of the particle distribution was $413 \mathrm{~nm}$. Using disc centrifugal sedimentation, a high degree of agglomeration in $\mathrm{NP}-\mathrm{FePO}_{4}$ following simulated GI digestion was observed, with only $20 \%$ of the particles $\leq 1000 \mathrm{~nm}$. In Caco-2 cells, divalent metal transporter-1 (DMT1) and endocytosis inhibitors demonstrated that NP-FePO was mainly absorbed via DMT1. Small particles may be absorbed by clathrin-mediated endocytosis and micropinocytosis. These findings should be considered when assessing the potential of iron nanoparticles for food fortification.
\end{abstract}

Keywords: nano iron; NP-FePO4; bioavailability; Caco-2 cells; simulated gastrointestinal digestion; DMT1; endocytosis

\section{Introduction}

Iron deficiency is the most prevalent nutritional deficiency in the world, affecting 1-2 billion people worldwide [1]. Food fortification is an effective strategy to reduce the burden of iron deficiency in populations [2,3]. Iron salts, iron chelates, and elemental powders are all iron sources approved for food fortification [3], but each form has inherent disadvantages. Soluble iron compounds, such as ferrous sulfate $\left(\mathrm{FeSO}_{4}\right)$ and ferrous gluconate, have high iron bioavailability but may cause adverse organoleptic changes when added to foods. Insoluble iron compounds, such as electrolytic iron and ferric phosphate $\left(\mathrm{FePO}_{4}\right)$, are stable in foods but have low iron bioavailability [4-6]. $\mathrm{FePO}_{4}$ is an iron compound that causes no adverse organoleptic changes in food matrices, but is poorly absorbed (25\%) relative to $\mathrm{FeSO}_{4}$ [4], therefore its nutritional value is limited.

The bioavailability of elemental iron powders has been shown to be inversely related to particle size. Harrison et al. [7] found that decreasing the particle size of $\mathrm{FePO}_{4}$ from 12-15 $\mu \mathrm{m}$ to $1 \mu \mathrm{m}$ increased iron solubility and improved relative biological value (RBV) 5-fold. Decreasing particle size 
to the nanoscale could be a strategy to improve iron bioavailability. Recently, $\mathrm{FePO}_{4}$ synthesized to the nanoscale (NP-FePO 4$)$ by flame spray pyrolysis (FSP) was reported to have similar iron bioavailability to $\mathrm{FeSO}_{4}$ in rat models [8]. This has been attibuted to its increased solubility as a result of higher surface area relative to its larger precursors. However, further studies are required to confirm that the findings in rats can be extrapolated to humans [9] given that rodents endogenously synthesize ascorbic acid [10] and are less affected by dietary inhibitors of iron absorption than humans [11]. In the present study, we examined the effects of in vitro simulated gastrointestinal digestion on the size distribution of NP-FePO , supernatant iron, uptake into Caco-2 cells, and mechanisms of absorption.

\section{Materials and Methods}

Samples of NP-FePO 4 , previously characterized for crystalline structure, phase distribution, chemical composition, and specific surface areas (SSA, 100 and $200 \mathrm{~m}^{2} / \mathrm{g}$ ) [8,12], were kindly donated by ETH Zurich.

\section{1. $\mathrm{NP}-\mathrm{FePO}_{4}$ Treatments: Sonication}

$\mathrm{NP}-\mathrm{FePO}_{4}$ was diluted to a concentration of $1 \mathrm{mg} / \mathrm{mL}$ either in water or minimum essential media (MEM). The suspensions were probe sonicated for 15 min (MSE Soniprep 150 Plus, London, UK) on maximum setting (Amplitude: 16.1 A, $150 \mathrm{~W}$ ).

\subsection{NP-FePO $\mathrm{P}_{4}$ Treatments: In Vitro Simulated Gastrointestinal (GI) Digestion}

$\mathrm{NP}-\mathrm{FePO}_{4}$ was exposed to in vitro simulated gastrointestinal digestion [13-15]. Briefly, $10 \mathrm{~mL}$ $40 \mathrm{mM} \mathrm{NaCl}$ and $5 \mathrm{mM} \mathrm{KCl} \mathrm{pH} 2$ solution containing $0.4 \%$ pepsin was added to NP-FePO 4 in a $50 \mathrm{~mL}$ polypropylene tube. The mixture was placed on a rotating table (100 rpm) and incubated for $1 \mathrm{~h}$ at $37^{\circ} \mathrm{C}$. After $1 \mathrm{~h}$, the $\mathrm{pH}$ of the digests was readjusted to $5.5-6.0$ and a pancreatin-bile solution $(0.25 \%)$ added. The $\mathrm{pH}$ was further adjusted to 6.9-7.0 with $1 \mathrm{M} \mathrm{NaHCO}_{3}$ and incubated for a further $30 \mathrm{~min}$ at $37^{\circ} \mathrm{C}$.

\subsection{Transmission Electron Microscopy (TEM)}

TEM micrographs were generated for visualization of $\mathrm{NP}^{-} \mathrm{FePO}_{4}(200)$ during in vitro digestion. During each digestion phase, an aliquot of digested $\mathrm{NP}^{-} \mathrm{FePO}_{4}$ (200) was drop spotted onto carbon-coated copper TEM mesh grids and dried for $1 \mathrm{~h}$. TEM mesh grids were washed 5 times with milliQ $\mathrm{H}_{2} \mathrm{O}$ and subsequently air-dried for $24 \mathrm{~h}$. Particles were visualized using a Jeol 1200EX electron microscope (JEOL, Tokyo, Japan) operated at $80 \mathrm{kV}$.

\subsection{Centrifugal Disc Sedimentation}

A CPS disc centrifuge model 2400 (CPS Instruments, Oosterhout, UK) was used to measure the total particle distribution given the heterogeneity, polydispersity, and aggregated/agglomerated particle patterns during in vitro digestion. The instrument was run at $5000 \mathrm{rpm}\left(20^{\circ} \mathrm{C}\right)$ for $30 \mathrm{~min}$. A sucrose gradient was established using two sucrose solutions ( $24 \%$ and $8 \% w / v)$. After setting of the gradient, the instrument was calibrated to polystyrene standards $(0.239 \mu \mathrm{m})$ followed by sample $(100 \mu \mathrm{L})$.

\subsection{Dynamic Light Scattering (DLS)}

Hydrodynamic particle size of $\mathrm{NP}-\mathrm{FePO}_{4}$ in cell culture media was measured using dynamic light scattering (DLS) with the Zetasizer Nano-ZS (Malvern Instruments, Malvern, UK). Particles $(1 \mathrm{mg} / \mathrm{mL}$ in MEM) were sonicated and analysed immediately. The refractive index of the material was considered as 1.68. Intensity-based particle sizes were converted and are reported as volume based [16]. 


\subsection{Caco-2 Cell Culture}

Caco-2 cells (HTB-37 ${ }^{\circledR}$ VA) from the American Type Culture Collection were grown in Dulbecco's Modified Eagle Medium (DMEM) supplemented with 10\% fetal bovine serum, 1\% non-essential amino acid solution, $1 \%$ penicillin/streptomycin, and 1\% L-glutamine. Cells were grown in $75 \mathrm{~cm}^{2}$ cell culture flasks (Greiner, UK) and incubated in 5\% carbon dioxide/95\% air atmosphere at constant humidity. The media was replaced every $2-3$ days. For iron uptake experiments, cells were seeded onto collagen-coated 6- or 12-well plates and grown for 12 days. After 12 days, cells were placed in MEM containing $19.4 \mathrm{mM}$ D-glucose, $26.2 \mathrm{mM} \mathrm{NaHCO}_{3}, 10 \mathrm{mM}$ PIPES (piperazine- $\mathrm{N}, \mathrm{N}$-bis-(2-ethanesulfonic acid)), $1 \%$ antibiotic-antimycotic solution, $4 \mathrm{mg} / \mathrm{L}$ hydrocortisone, $5 \mathrm{mg} / \mathrm{L}$ insulin, $0.02 \mu \mathrm{M} \mathrm{Na}_{2} \mathrm{SeO}_{3}$, $0.05 \mu \mathrm{M}$ triiodothyronine and $0.2 \mathrm{mg}$ epidermal growth factor for $24 \mathrm{~h}$ prior to iron treatments. Experiments were conducted using cell passages 25-40.

\subsection{Supernatant Iron during In Vitro Gastric Digestion}

Supernatant iron from NP-FePO 4 (soluble and $<100 \mathrm{~nm}$ fractions) was quantified after iron dissolution at low $\mathrm{pH}[12,17]$. Supernatant iron was measured with respect to time and $\mathrm{pH}$ at the end of the gastric phase. At each time point, $1 \mathrm{~mL}$ aliquots were removed from digestion and centrifuged immediately for $5 \mathrm{~min}$ at $11,600 \times \mathrm{g}$. The supernatant was removed and analyzed for iron content against a non-centrifuged control (total iron). The iron content of samples was determined using the iron chelator, 3-(2-pyridyl)-5,6-bis(5-sulfo-2-furyl)-1,2,4-triazine, disodium salt trihydrate (Ferene-S, Sigma, Gillingham, UK) with ammonium iron (II) sulfate as the iron standard curve. Briefly, $100 \mu \mathrm{L}$ sample was diluted in $100 \mu \mathrm{L} 1 \% \mathrm{HCl}$ and incubated at $80{ }^{\circ} \mathrm{C}$ for $10 \mathrm{~min}$. Samples were cooled on ice, followed by sequential addition of $500 \mu \mathrm{L} \mathrm{7.5 \%}$ ammonium acetate, $100 \mu \mathrm{L} 2.5 \%$ sodium

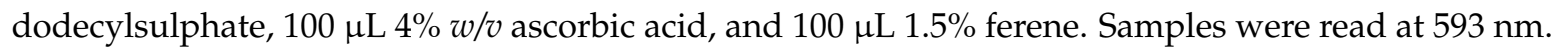

\subsection{Measurement of Iron Uptake into Caco-2 Cells}

Iron uptake into Caco-2 monolayers was determined using cell ferritin formation (ng cell ferritin/mg cell protein). In each cell culture experiment, ferric ammonium citrate (FAC) was included as a control. FAC is a well-absorbed form of iron in Caco-2 cells and used as the reference for DMT1 uptake [18-20]. Reference blanks (cells not treated with iron) were included in each experiment to ensure low baseline levels of cell ferritin. After iron treatment, cells were washed twice with PBS and lysed with $200 \mu \mathrm{L}$ CelLytic M protein lysis buffer (Sigma). Lysed cells were centrifuged $(14,000 \times g$, $15 \mathrm{~min}$ ), supernatants collected, and analyzed for cell ferritin using the Spectroferritin ELISA kit (ATI Atlas, Chichester, UK). Cell ferritin was normalized to total protein concentrations using the BCA protein assay kit (ThermoFisher Scientific, Loughborough, UK).

\subsection{Chemical Inhibitors Targeting Iron Uptake}

All chemicals, unless otherwise stated, were from Sigma and used at the following concentrations. For in vitro simulated GI digestion experiments, ascorbic acid (AA) (1:20 Fe:AA molar ratio, $600 \mu \mathrm{M})$ was added at the beginning of the gastric phase as an enhancer of non-haem iron bioavailability. $2.5 \mathrm{mM}$ $\mathrm{CaCl}_{2}$ (after dilution with digests) was added directly in MEM and used as an inhibitor of non-heme iron bioavailability. In both conditions, digests were incubated with cells for $24 \mathrm{~h}$. For sonicated NP-FePO 4 (200), clathrin-mediated endocytosis was inhibited using chlorpromazine hydrochloride $(100 \mu \mathrm{M})$ and sucrose $(0.5 \mathrm{M})$. Clathrin-independent endocytosis targeting caveolae-mediated endocytosis and macropinocytosis were inhibited with filipin $(5 \mathrm{mg} / \mathrm{L})$ and dimethyl amiloride (DMA, $200 \mu \mathrm{M})$, respectively [21-26]. Caco-2 cells were co-incubated with iron treatment and endocytosis inhibitors for $1 \mathrm{~h}$, removed, and incubated for a further $23 \mathrm{~h}$. 


\subsection{0. siRNA Knockdown of DMT1 in Intestinal Epithelial Cells}

Caco-2 cells, seeded into 12-well collagen-coated plates (200,000 cells/well), were grown for 10 days. Transient knockdown of DMT1 was initiated according to the method of Latunde-Dada et al. 2014 [27]. Cell monolayers were transfected with Silencer ${ }^{\circledR}$ Select siRNA targeting SLC11A2 (the gene encoding DMT1) or Negative control no. 1 ( $200 \mathrm{nM}$, Life Technologies) using Lipofectamine 3000 in Opti-MEM (Gibco) for $48 \mathrm{~h}$. After $48 \mathrm{~h}$, siRNA complexes were replaced with FAC or NP-FePO (200) for $2 \mathrm{~h}$. Iron treatments were removed, MEM added, and cells were incubated for a further $22 \mathrm{~h}$. Wells in parallel with the same treatments were used to analyze for cell ferritin/protein and RNA extraction prior to RT-PCR. For Hutu- 80 cells, 12-well plates (100,000 cells/well) were grown until $50 \%-70 \%$ confluent. Cell monolayers were transfected with Silencer ${ }^{\circledR}$ Select siRNA targeting SLC11A2 or Negative control no. $1(10 \mathrm{nM})$ in Opti-MEM for 48 hours. Iron treatments and incubations paralleled the siRNA knockdown experiments undertaken in Caco-2 cells. Cell ferritin formation was normalised to FAC for siRNA experiments.

\subsection{RT-PCR}

The RNeasy Mini Kit (Qiagen, Hilden, Germany) was used for RNA extraction according to manufacturer's instructions. RNA quality was determined using UV-Vis Nanodrop 2000 spectrophotometer (ThermoFisher Scientific, Loughborough, UK). Complementary DNA (cDNA) was synthesized using the qPCRBIO cDNA Synthesis Kit (PCR Biosystems, London, UK). $0.1 \mathrm{mg}$ RNA was reverse transcribed to cDNA. Predesigned primers (KiCqStart SYBR Green Primers, Sigma, Gillingham, UK): SLC11A2, Forward: GAG TAT GTT ACA GTG AAA CCC; Reverse: GAC TTG ACT AAG GCA GAA TG; 18S, Forward: ATC GGG GAT TGC AAT TAT TC; Reverse: CTC ACT AAA CCA TCC AAT CG. Real time PCR proceeded with $4 \mu \mathrm{L}$ cDNA and $2 \times$ SYBR Green Mix Lo-ROX (PCR Biosystems) and run using the Roche Lightcycler 480 (Roche, Burgess Hill, UK). Relative expression of SLC11A2 (DMT1) was normalised to the housekeeping gene 18S, and assessed using the $\Delta \Delta \mathrm{Ct}$ method [28].

\subsection{Statistical Analysis}

Statistical analysis was performed using GraphPad Prism v.6.0 (San Diego, CA, USA). Particle size was calculated using Feret's diameter and particle size distributions expressed using the median particle size (d50) with d10 representing $10 \%$ and $\mathrm{d} 90$ representing $90 \%$ of the particle sizes. One-way repeated measures ANOVA with Tukey's multiple comparisons test was used to compare differences in iron uptake or one-way repeated measures ANOVA with Dunnett's test were used to compare differences between NP-FePO 4 (200) and NP-FePO 4 (200) treated with chemical inhibitors. Cell culture experiments were repeated 2-3 times, with $n=3$ per experiment. Differences were considered significant at $p<0.05$.

\section{Results}

\subsection{Particle Size}

\subsubsection{Characterization of Sonicated NP-FePO 4}

Sonicated NP-FePO 4 (200) and NP-FePO 4 (100) particle sizes were characterized in MEM using DLS. Sonicated NP-FePO 4 (200) hydrodynamic diameter averaged $341 \mathrm{~nm}(\mathrm{~d} 10, \mathrm{~d} 90:$ 190, 459) and NP-FePO 4 (100), $458 \mathrm{~nm}(\mathrm{~d} 10, \mathrm{~d} 90: 342,532)$ (Figure 1A,B). Visual morphology of NP-FePO 4 (200) comparing diluted (non-sonicated) or dispersed (sonicated) particles was conducted using TEM with water as the diluent. Large, agglomerated, electron dense particles formed without sonication in the micron range (Figure 1C) with $\mathrm{d} 50=1990 \mathrm{~nm}$ (Figure 2B). Sonication of $\mathrm{NP}^{-\mathrm{FePO}_{4}}$ (200) resulted in particle dispersal of similar size to the acquired DLS data (Figure 1D); $\mathrm{d} 50=312 \mathrm{~nm}$. 
A

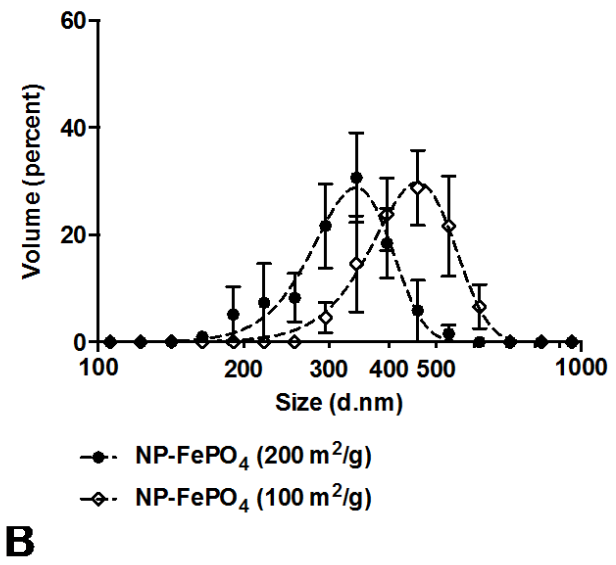

C

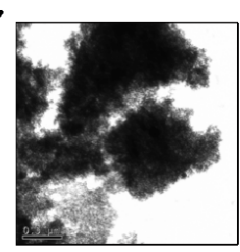

D

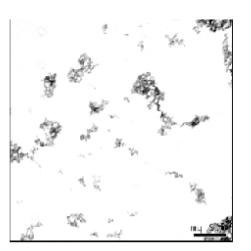

\begin{tabular}{ccccccc}
\hline & SSA & Estim ated & Hydrodynam ic & & & \\
Particle & $\left(\mathrm{m}^{2} / \mathrm{g}\right)$ & $\begin{array}{c}\text { MPS (nm) } \\
\text { MPam eter (nm) }\end{array}$ & dv10 & dv50 & dv90 \\
\hline \hline NP-FePO $_{4}(200)$ & 200 & 10 & 341 & 220 & 342 & 396 \\
$\mathrm{NP}_{-} \mathrm{FePO}_{4}(100)$ & 100 & 20 & 458 & 342 & 459 & 531
\end{tabular}

Figure 1. Size determination of sonicated nano-sized ferric phosphate (NP-FePO $)_{4} .1 \mathrm{mg} / \mathrm{mL} \mathrm{NP}-\mathrm{FePO}_{4}$ dispersions in minimum essential media (MEM) were measured using dynamic light scattering, $n=3(\mathbf{A}, \mathbf{B}) .1 \mathrm{mg} / \mathrm{mL} \mathrm{NP}-\mathrm{FePO}_{4}$ (200) directly diluted in $\mathrm{H}_{2} \mathrm{O}$ (unsonicated) (C) or dispersed by sonication and visualized using transmission electron microscopy (TEM) (D). SSA, specific surface areas; MPS, mean particle size.

A

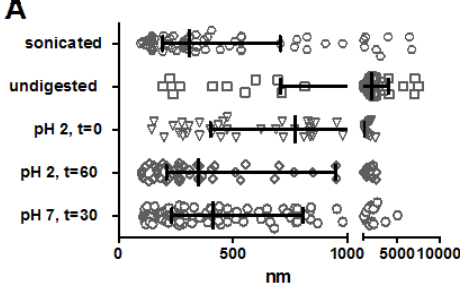

$\mathbf{B}$

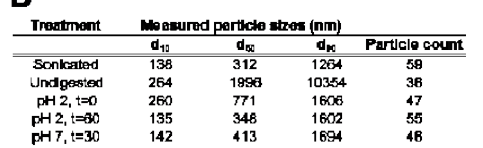

c

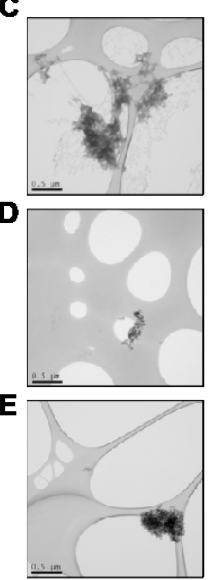

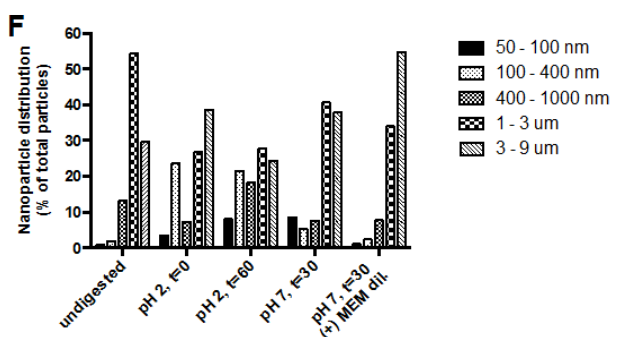

Figure 2. Size determination of $\mathrm{NP}_{-}-\mathrm{FePO}_{4}(200)$ during different stages of in vitro digestion. $1 \mathrm{mg} / \mathrm{mL}$ stock solutions in water were diluted to $30 \mu \mathrm{g} / \mathrm{mL}$ in digestion solutions, and visualised using TEM. Particle sizes were calculated using ImageJ software analysis (A) and particle size distributions reflected in the table (B). Representative TEM micrographs used in the analysis of size and size distributions at $\mathrm{pH} 2, t=0 \mathrm{~min}(\mathrm{C}), \mathrm{pH} 2, t=60 \mathrm{~min}(\mathbf{D})$, and $\mathrm{pH} 7, t=30 \mathrm{~min}(\mathrm{E})$. Histogram of particle distribution based upon total particle population during stages of in vitro digestion $(\mathbf{F})$.

\subsubsection{In Vitro Simulated GI Digested NP-FePO 4 (200)}

Particle size of NP-FePO 4 (200) during in vitro digestion was visualized using TEM and particle size analysis with ImageJ software. Non-digested particles agglomerated in water as previously shown, resulting in $\mathrm{d} 50=1996 \mathrm{~nm}$. The particle size shifted to d50 =771 $\mathrm{nm}$ after exposure to initial gastric digestion ( $\mathrm{pH}$ 2). 60 min exposure in $\mathrm{pH} 2$ caused further reduction of particle size to $\mathrm{d} 50=348 \mathrm{~nm}$. The particle size slightly agglomerated to $\mathrm{d} 50=413 \mathrm{~nm}$ after the in vitro digest was neutralized $(\mathrm{pH} 7$, 
$t=30$ ) with $0.1 \mathrm{M} \mathrm{NaHCO}_{3}$ (Figure 2A,B). Total particle population size distibutions during in vitro

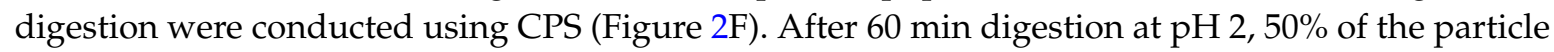
sizes were $\leq 1000 \mathrm{~nm}$, and $30 \%$ of the particles were $\leq 400 \mathrm{~nm}$. At pH 7, rapid agglomeration of the particles led to an $80 \%$ increase in micron-sized fractions, and the proportions of the 100-400 nm and $400-1000 \mathrm{~nm}$ fractions were reduced to $<10 \%$. Overall, about $15 \%$ of the particles were $\leq 400 \mathrm{~nm}$ after in vitro digestion.

\subsection{Cell Culture Experiments}

\subsubsection{Effect of Gastric $\mathrm{pH}$ and Time on Supernatant Iron and Uptake into Caco-2 Cells}

The effects of time of exposure and $\mathrm{pH}$ on supernatant iron concentration and uptake were compared using Caco-2 cells. At pH 2, NP-FePO 4 (100 and 200) was digested for 30, 60, and $120 \mathrm{~min}$ and aliquots were taken to determine supernatant iron. The remaining digestion solution was neutralized at $\mathrm{pH} 7$ and incubated for a further $30 \mathrm{~min}$ for cellular iron uptake. Supernatant iron increased with longer gastric digestion times, but no significant difference was observed between the two particle sizes. Compared to FAC, $\mathrm{NP}-\mathrm{FePO}_{4}$ supernatant iron reached $70 \%$ after $2 \mathrm{~h}$ digestion (Figure $3 \mathrm{~A}$ ). Iron uptake was significantly increased when $\mathrm{NP}-\mathrm{FePO}_{4}$ was digested for $120 \mathrm{~min}$ compared to $30 \mathrm{~min}$ for both particle sizes but only half as absorbed compared to FAC (Figure 3C). In contrast, the $\mathrm{pH}$ of the gastric digest had a large effect on supernatant iron and uptake of iron from $\mathrm{NP}-\mathrm{FePO}_{4}$. Iron was completely in the supernatant fraction when $\mathrm{NP}^{-}-\mathrm{FeO}_{4}$ was digested at $\mathrm{pH} 1$, whereas $5 \%-10 \%$ of iron was in the supernatant at $\mathrm{pH} 4$ for both particles (Figure 3B). NP-FePO 4 was not taken up (compared to controls not containing iron) after digesting both particles at $\mathrm{pH} 4$ for $1 \mathrm{~h}$. Iron uptake from $\mathrm{NP}^{-\mathrm{FePO}_{4}}$ (200) was significantly increased relative to $\mathrm{NP}^{-}-\mathrm{FePO}_{4}(100)$ when digested at $\mathrm{pH} 1$ and similar to FAC (Figure 3D).
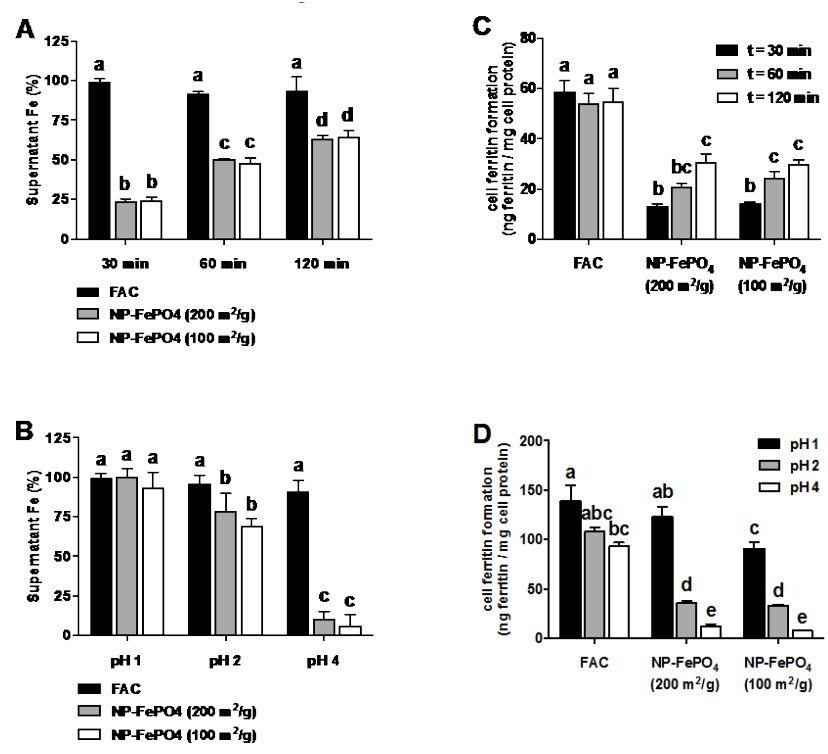

Figure 3. Effect of gastric digestion on supernatant iron and iron uptake in Caco-2 cells. Ferric ammonium citrate (FAC) or $\mathrm{NP}^{-}-\mathrm{FePO}_{4}(30 \mu \mathrm{M} \mathrm{Fe})$ was digested at $\mathrm{pH} 2$ for varying times (A) or digested at varying $\mathrm{pH}$ for 1 hour $(\mathbf{B})$ and supernatant iron determined at the end of gastric digestion. Caco-2 cells were exposed to digested FAC or NP-FePO $4(30 \mu \mathrm{M} \mathrm{Fe})$ for $24 \mathrm{~h}$ and measured for cell ferritin formation (C,D). Data values are expressed as the means of two independent experiments $(n=3$ per experiment, \pm standard error of the mean (SEM)). One-way repeated measures analysis of variance (ANOVA) with Tukey's multiple comparisons test was used to compare differences in iron uptake between iron treatment $\left(\mathrm{FAC}\right.$ or $\mathrm{NP}-\mathrm{FePO}_{4}$ ) with time or $\mathrm{pH}$. Different letters indicate statistically significant differences $(p<0.05)$. 


\subsubsection{Effect of $A A$ and Calcium on Iron Uptake in Caco-2 Cells}

$\mathrm{NP}-\mathrm{FePO}_{4}$ was digested using standard in vitro gastrointestinal conditions. Particles were digested at $\mathrm{pH} 2$ for $1 \mathrm{~h}$ and $\mathrm{pH} 7$ for $30 \mathrm{~min}$. Ascorbic acid added to the digest (1:20 AA molar ratio) during the gastric phase increased iron uptake of FAC 2-fold and both forms of NP-FePO 3-4 fold. The increase in iron uptake of NP-FePO 4 with added AA was similar to FAC and FAC with AA (Figure 4A), correlating with increased supernatant iron of $\mathrm{NP}^{-} \mathrm{FePO}_{4}$ with AA at neutral $\mathrm{pH}$ (Supplementary Figure S1). NP-FePO 4 was digested and added to MEM containing a final concentration of $2.5 \mathrm{mM} \mathrm{CaCl}_{2}$ after dilution (Figure 4B). Calcium (as $\mathrm{CaCl}_{2}$ ) inhibited iron uptake from FAC and NP-FePO 4 (200) by $50 \%$. Iron uptake of $\mathrm{NP}^{-} \mathrm{FePO}_{4}(100)$ was marginally decreased with $\mathrm{CaCl}_{2}$ but the effect was not statistically significant, which might be due to the low basal levels of iron uptake observed (Figure 4B).
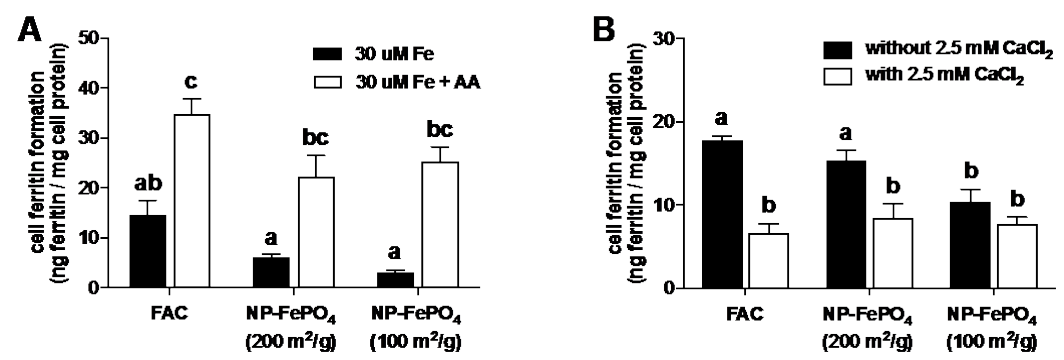

Figure 4. Iron uptake of in vitro simulated GI digested FAC or NP-FePO 4 after incubation with ascorbic acid (1:20 AA molar ratio) introduced at the gastric phase or $\mathrm{CaCl}_{2}$ (2.5 $\mathrm{mM}$, final volume in MEM after dilution) in Caco-2 cells after $24 \mathrm{~h}$. Caco-2 cells were exposed to digested FAC or NP-FePO $(30 \mu \mathrm{M} \mathrm{Fe})$ and incubated with ascorbic acid (A) or $\mathrm{CaCl}_{2}$ in MEM (B) for $24 \mathrm{~h}$ and measured for cell ferritin formation. Data values are expressed as the means of two independent experiments $(n=3$ per experiment, \pm SEM). One-way repeated measures ANOVA with Tukey's multiple comparisons test was used to compare differences in iron uptake between iron treatment (FAC or NP-FePO 4 ) with enhancer (AA) or inhibitor $\left(\mathrm{CaCl}_{2}\right)$. Different letters indicate statistically significant differences $(p<0.05)$.

Using sonicated NP-FePO 4 (200), $\mathrm{CaCl}_{2}$ did not inhibit iron uptake. Iron uptake was significantly reduced when sonicated particles were incubated in the presence of chlorpromazine, sucrose, and DMA (Figure 5).

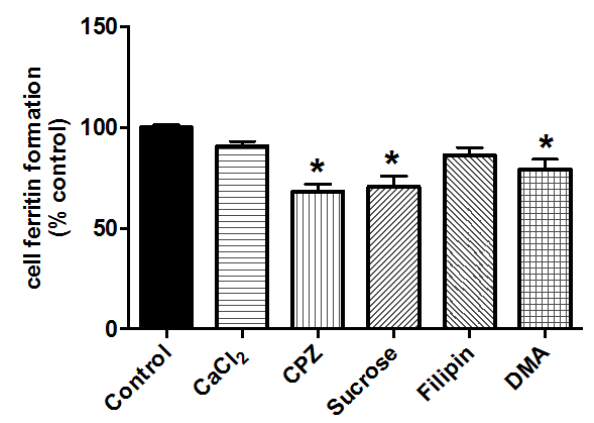

Figure 5. Iron uptake of sonicated $\mathrm{NP}^{-}-\mathrm{FeO}_{4}$ (200) co-incubated with chemical inhibitors targeting endocytosis uptake pathways in Caco-2 cells as measured by cell ferritin formation. NP-FePO 4 (200) $(100 \mu \mathrm{M} \mathrm{Fe})$ was incubated directly in MEM with inhibitors and placed onto Caco-2 cells for $1 \mathrm{~h}$. Cells were washed $3 \times$ with PBS and replaced with MEM for a further $23 \mathrm{~h}$. Data values are expressed as the means of two independent experiments ( $n=3$ per experiment, \pm SEM). One-way repeated measures ANOVA with Dunnett's multiple comparison test was used to distinguish differences in iron uptake between control (NP-FePO 4 (200)) and NP-FePO 4 (200) co-incubated with chemical inhibitors. Asterisks indicate statistically significant differences from control $(p<0.05)$. 


\subsubsection{Effect of siRNA-Mediated Knockdown of DMT1 in Caco-2 and Hutu-80 Cells}

Under our experimental conditions, DMT1 expression was reduced by $20 \%$ in Caco-2 cells following exposure to SLC11A2 siRNA (Figure 6A). The reduction in DMT1 expression was sufficient to significantly reduce iron uptake from FAC by $20 \%$. Iron uptake from sonicated NP-FePO $(200)$ was not different in siRNA DMT1 treated cells (Figure 6B) relative to control cells. However, uptake from digested NP-FePO 4 (200) was decreased in DMT1-knockdown cells (Figure 6C).

The Hutu-80 cell line was used to validate DMT1 knockdown of Caco-2 cells, since its transfection efficiency is improved in comparison to Caco- 2 cells. DMT1 expression was reduced by $50 \%$ in Hutu- 80 cells. In both digested and sonicated NP-FePO 4 (200), DMT1 knockdown resulted in significant inhibition of iron uptake by $40 \%-50 \%$ (Figure 6 C,D). In both cell lines, DMT1 expression from negative control siRNA was not different than from control cells without siRNA.

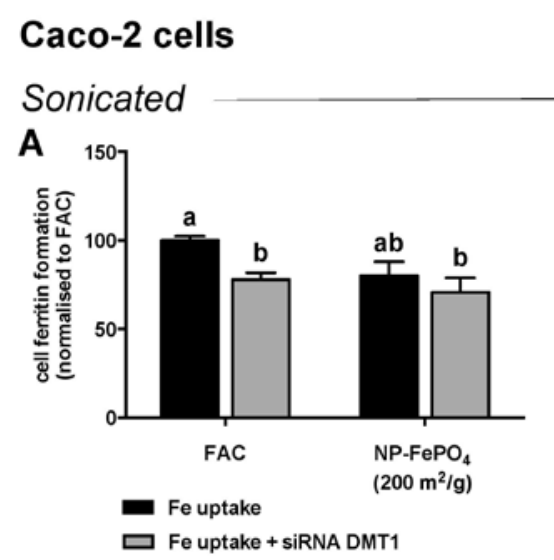

\section{Hutu-80 cells}
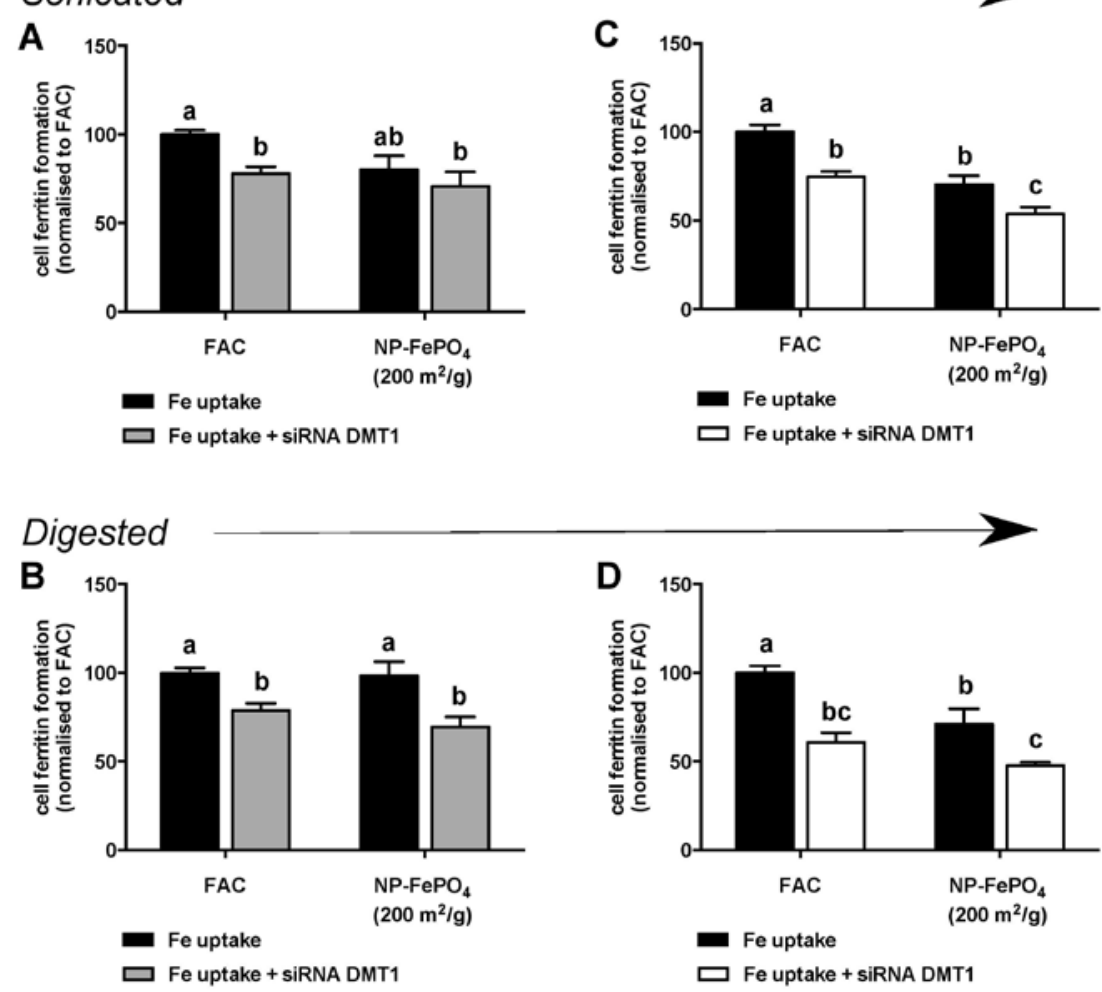

Figure 6. Iron uptake of sonicated and in vitro digested $\mathrm{NP}-\mathrm{FePO}_{4}(200)$ or $\mathrm{FAC}$ in non-targeting siRNA (negative control 1) or SLC11A2 siRNA treated Caco-2 cells (A,B) or Hutu-80 cells (C,D) after $2 \mathrm{~h}$ exposure followed by incubation in MEM for a further $22 \mathrm{~h}$. Cell ferritin formation was normalized relative to FAC treatments. Data values are expressed as the means of three independent experiments $(n=3$ per experiment, \pm SEM). One-way repeated measures ANOVA with Tukey's multiple comparisons test was used to compare differences in iron uptake between iron treatment (FAC or NP-FePO 4 [200]) in non-targeting siRNA or SLC11A2 siRNA treated cells. Different letters indicate statistically significant differences $(p<0.05)$.

\section{Discussion}

Food iron fortification is technically challenging as the fortificant cannot react with food matrices. The elemental powders H-reduced, carbonyl, electrolytic iron, $\mathrm{FePO}_{4}$, and ferric orthophosphate do not react with food matrices and are widely used. However, low iron bioavailability of elemental powders relative to water-soluble compounds limit their nutritional value. Particle size reduction 
is an effective strategy for improving iron bioavailability from elemental powders [29]. Particle size reduction is inversely related to iron solubility at low $\mathrm{pH}$, which has been shown to be the best in vitro predictor of iron bioavailability in humans $[17,30]$. The advent of nanotechnology has facilitated the synthesis of "micro" and "nano" sized particles with defined size and morphology. Recent studies have demonstrated good iron bioavailability of micronized ferric pyrophosphate (SunActive@ Fe, Yokkaichi Japan), with estimated mean particle size of $0.3 \mu \mathrm{m}$, in humans [31-34]. The bioavailability of $\mathrm{NP}-\mathrm{FePO}_{4}$ has been shown to be effective as ferrous sulfate in rats using the hemoglobin repletion assay $[8,12]$. The present study aimed to elucidate the mechanisms involved in iron uptake from $\mathrm{NP}-\mathrm{FePO}_{4}$ using cellular models.

We investigated two separate mechanisms of iron uptake into Caco-2 cells; iron uptake via DMT1, and direct endocytosis of NP-FePO 4 . We first characterised NP-FePO 4 in solution. Nanoparticle toxicity is a concern since small particle size is a factor that can lead to enhanced rates of translocation into body tissues. With increasing interest in using iron nanoparticles as food fortificants, it is possible that non-homeostatically regulated iron uptake may occur, resulting in oxidative stress. An assessment of the toxicity of specific particles includes consideration of particle size, dispersity, agglomeration state, surface characteristics, charge, and cell type, as each parameter is an important factor determining nanoparticle uptake [35-38].

In addressing exposure of Caco-2 cells to NP-FePO during a physiologically relevant exposure using a validated in vitro method [13,39]. This method estimates iron bioavailability from an in vitro simulated GI digestion/Caco-2 cell model and has shown to correlate well with data from human trials [40,41]. Using disc centrifugal sedimentation (DCS), the majority of particles agglomerated when $\mathrm{NP}^{-} \mathrm{FePO}_{4}(200)$ was exposed to simulated in vitro digestion. Agglomerated particle fractions suggest limited toxicity of $\mathrm{NP}-\mathrm{FePO}_{4}(200)$ to the intestinal epithelium with respect to its smaller (dried) precursors [11,21,27]. Agglomeration of particles was not observed using TEM, which is likely due to technical differences in microscopy and laser diffraction [28].

Next we examined the effects of gastric digestion on iron uptake of $\mathrm{NP}-\mathrm{FePO}_{4}$ in Caco-2 cells. We use the term supernatant iron throughout, rather than soluble iron, as it accurately describes the nature of the aqueous phase containing a combination of soluble iron and nanoparticles $<100 \mathrm{~nm}$ after centrifugation when $3 \mathrm{kDa}$ molecular weight cut off (MWCO) spin filters are omitted [16,26]. Cell ferritin formation served as the surrogate marker of iron absorption [8,33]. Gastric digestion at $\mathrm{pH} 1$ for $1 \mathrm{~h}$ significantly increased supernatant iron and iron uptake compared to $\mathrm{pH} 2$ and $\mathrm{pH} 4$. Gastric digestion at pH 2 for $30 \mathrm{~min}, 60 \mathrm{~min}$, and $120 \mathrm{~min}$ led to increases in supernatant iron and uptake with time, but the effect of time was much less pronounced than $\mathrm{pH}$. Coupling gastric digestion at $\mathrm{pH} 1$ to Caco-2 cells resulted in more bioavailable iron from $\mathrm{NP}_{-}-\mathrm{FePO}_{4}(200)$ compared to $\mathrm{NP}-\mathrm{FePO}_{4}$ (100). Iron uptake of NP-FePO 4 (200) was similar to FAC. Rohner et al. [6] and Hilty et al. [7] observed similar iron uptake of $\mathrm{NP}^{-} \mathrm{FePO}_{4}(200)$ compared to $\mathrm{FeSO}_{4}$ in rats and suggested that its high iron uptake is a result of increased iron particle dissolution compared to commonly used $\mathrm{FePO}_{4}$.

While iron bioavailability of foods and the effects of dietary factors using the in vitro digestion/Caco-2 cell model has been shown to correlate well with human absorption data [40,41], the usefulness of the model for elemental iron powders as a predictor for human bioavailability has been questioned [5,42]. Breads fortified with 8 micron sized H-reduced iron were more bioavailable than breads fortified with 45 micron sized H-reduced iron in Caco-2 cells, and a linear relationship was found between solubility and iron bioavailability [43]. Similarly, 40-60 nm H-reduced iron particles were more bioavailable compared to its larger precursors [44]. Others have found that the Caco-2 cell model cannot consistently predict the bioavailability of iron fortificants within food matrices that have been observed in humans $[45,46]$. Forbes et al. compared two iron fortificants, electrolytic iron and ferric orthophosphate, with $\mathrm{FeSO}_{4}$ using in vitro solubility at $\mathrm{pH} 1.2$ and absorption studies in humans [4]. The compounds were ranked in the same order (ferrous sulfate $>$ electrolytic iron $>$ ferric orthophosphate), although the solubility test underestimated the relative biological value of ferric 
orthophosphate. They concluded that these results, together with those from earlier studies, suggested that solubility in dilute acid provides a screening method for assessing iron fortification compounds. However, $\mathrm{pH} 1.2$ is non-physiological because it is lower than the $\mathrm{pH}$ found within the stomach. In our experiments, we observed that the supernatant iron concentration from $\mathrm{NP}-\mathrm{FePO}_{4}$ at $\mathrm{pH} 1$ was equal to that of FAC, and that there was a positive correlation with Caco-2 cell ferritin concentration; iron uptake of NP-FePO 4 (200) was equal to that of FAC at pH 1. These results indicate that the dissolution of nano-particulate iron is a function of gastric $\mathrm{pH}$.

We investigated the role of DMT1 transport in iron uptake from digested NP-FePO ${ }_{4}$ in Caco-2 cells. Two to 4-fold increases in ferritin formation were observed when AA was added to the gastric digest with $\mathrm{NP}-\mathrm{FePO}_{4}$, similar to FAC. AA is a potent enhancer of non-heme iron absorption which occurs via reduction of $\mathrm{Fe} 3+$ to $\mathrm{Fe} 2+$ and solubility at intestinal $\mathrm{pH}[10,47]$. Our data suggest that AA increases iron uptake of NP-FePO${ }_{4}$, similar to FAC and FAC + AA in Caco-2 cells, by facilitating $\mathrm{Fe}^{2+}$ DMT1 mediated uptake. We further confirmed that iron uptake from $\mathrm{NP}-\mathrm{FePO}_{4}$ occurred via DMT1 by incubating Caco-2 cells with $2.5 \mathrm{mM} \mathrm{CaCl}_{2}$. Calcium has been shown to inhibit non-heme iron uptake in Caco-2 cells by decreasing apical protein expression of DMT1 [20]. Iron uptake from in vitro digested $\mathrm{FAC}$ and $\mathrm{NP}-\mathrm{FePO}_{4}$ was reduced when incubated with $\mathrm{CaCl}_{2}$, providing evidence that DMT1 is required for iron uptake. Using siRNA to target DMT1 in both Caco-2 and Hutu-80 cell lines demonstrated that iron uptake was decreased in DMT1 knockdown cells compared to control cells in both cell lines, thereby confirming the role of DMT1 in iron uptake from NP-FePO 4 .

DMT1 transport is most likely the predominant mechanism of iron uptake. We also speculated that an alternative route of iron uptake is also operational, given that $\sim 15 \%$ of the particles were between 50 and $400 \mathrm{~nm}$ (Figure 2F). Gastric $\mathrm{pH}$ in rats is considerably higher than $\mathrm{pH} 1$ [48,49] and our experiments showed that a large amount of iron (25\%-50\%) from $\mathrm{NP}-\mathrm{FePO}_{4}$ remained insoluble at $\mathrm{pH} 2$, with little iron in the supernatant fraction at $\mathrm{pH} 4$. This suggests that a significant fraction of iron bound to NP-FePO 4 could be directly transported into the epithelium by endocytosis, given particle translocation of 200 and $500 \mathrm{~nm}$ particles seen in Caco-2 cells co-cultured with M-cell like phenotype [36,50]. This was investigated using sonicated NP-FePO${ }_{4}$. The particle size range of sonicated $\mathrm{NP}-\mathrm{FePO}_{4}(200)$ was similar to the range expected for the non-agglomerated fraction of in vitro digested $\mathrm{NP}-\mathrm{FePO}_{4}(200)$. Iron uptake from sonicated $\mathrm{NP}-\mathrm{FePO}_{4}(200)$ was inhibited with chlorpromazine and sucrose, and to a lesser extent DMA (Figure 5). The chemical inhibitors used have been shown to be successful in inhibiting endocytic pathways in Caco-2 cells [24-26]. We did not observe an effect on iron uptake from sonicated $\mathrm{NP}-\mathrm{FePO}_{4}$ with $\mathrm{CaCl}_{2}$, suggesting that uptake is independent of DMT1. This needs to be further clarified as excess calcium may cause particle agglomeration. Sonicated NP-FePO 4 (200) had a wide particle distribution (150-500 nm), therefore we hypothesize that the smaller particles may be absorbed using clathrin-mediated endocytosis and the larger particles using macropinocytosis. In recent reports, TEM micrographs of nanoparticle uptake have been observed for iron compounds from 10-100 nm size in Caco-2 cells [26,51,52]. Moreover, in support of our findings, a number of previous studies have shown that nano-sized iron compounds are absorbed using endocytic pathways in Caco-2 cells $[22,23,26]$. This suggests that our data are not the result of increased transcytosis of $\mathrm{NP}-\mathrm{FePO}_{4}(200)$ caused by toxic effects induced by iron treatment or chemical inhibitors (Supplementary Figure S2).

The long-term exposure and potential toxicity to $\mathrm{NP}-\mathrm{FePO}_{4}$ require further investigation. Health concerns have been raised about the toxicological effects of daily consumption of nanoparticles found in various consumer products (see review by $\mathrm{Nel}$ et al. [35]). Although evidence from our study suggests that $\mathrm{NP}-\mathrm{FePO}_{4}$ is non-toxic to Caco-2 cells after $24 \mathrm{~h}$ exposure, recent studies have shown that chronic exposure of polystyrene or TiO2 nanoparticles to Caco-2/HT-29 MTX co-cultures markedly remodel the intestinal epithelium and affect iron absorption [53,54].

The future use of $\mathrm{NP}-\mathrm{FePO}_{4}$ as an iron fortificant is to some extent dependent on factors other than nutritional considerations. Food fortification for large-scale populations requires that the iron compound is cost-effective and scalable. Although inherent disadvantages exist in the use of $\mathrm{FeSO}_{4}$ 
as a fortificant, namely its rancidity/instability during storage and color induced changes to the matrix [5,7], its use meets the criteria described above compared to other iron compounds, such as NaFeEDTA and FePP [55]. Advances in nanotechnology necessitate decreasing the cost and increasing the scalability of production prior to its use as an iron fortificant.

\section{Conclusions}

Our experiments demonstrate that iron uptake from $\mathrm{NP}-\mathrm{FePO}_{4}$ occurred predominately through increased iron in the supernatant fraction and entry via the DMT1 transporter in the Caco-2 cell model. Some NP-FePO 4 (200) may be absorbed intact in Caco-2 cells independently from DMT1, but most likely this mechanism has a minor role in iron uptake. We reach this conclusion because our digestion experiments showed less than $15 \%$ of $\mathrm{NP}-\mathrm{FePO}_{4}$ (200) remained as particles $<400 \mathrm{~nm}$, and in our sonicated NP-FePO 4 (200) experiments, chlorpromazine and siRNA DMT1 treated cells inhibited $20 \%$ of iron uptake. Our results suggest that $\mathrm{NP}-\mathrm{FePO}_{4}(200)$ endocytosis in Caco-2 cells is dependent on particle size, with clathrin-mediated endocytosis (CME) as the predominant mechanism of particle internalization. To our knowledge, this is the first paper suggesting a mechanism of particle transcytosis of iron compounds for food fortification. However, one of the assumptions made in our experiments is that sonicated particles are similar to the nanoparticle fractions after in vitro digestion, which illustrates the difficulties in translating the relatively novel field of nanotechnology to biological systems. Nevertheless, our experiments suggest that the iron uptake from NP-FePO 4 (200) results from both DMT1 transport and particle transcytosis, which should be taken into consideration when assessing the potential of iron nanoparticles for food fortification.

Supplementary Materials: The following are available online at www.mdpi.com/2072-6643/9/4/359/s1, Figure S1: Supernatant iron of digested NP-FePO 4 after in vitro simulated GI digestion, Figure S2: Cell viability of Caco-2 cells measured $4 \mathrm{~h}$ or $24 \mathrm{~h}$ after incubation with chemical inhibitors or iron compounds.

Acknowledgments: This work was supported by the University of East Anglia International PhD Studentship, and the Facility for Environmental Nanoscience Analysis and Characterisation (FENAC). No funds were provided for covering the costs to publish in open access.

Author Contributions: A.P., C. E., E.V.-J., P.S. and S.F.-T. conceived and designed, the experiments and F.H. provided the nano iron and expertise related to iron bioavailability. A.P. and C.E. performed the experiments and analyzed the data, and A.P. and S.F.-T. wrote the paper. All authors critically reviewed and contributed to the final draft. The work described in this paper forms part of A.P.'s PhD project, supervised by S.F.-T. and P.S.

Conflicts of Interest: The authors declare no conflict of interest. The founding sponsors had no role in the design of the study; in the collection, analyses, or interpretation of data; in the writing of the manuscript, and in the decision to publish the results.

\section{References}

1. Zimmermann, M.B.; Hurrell, R.F. Nutritional iron deficiency. Lancet 2007, 370, 511-520. [CrossRef]

2. Hurrell, R.F. Preventing iron deficiency through food fortification. Nutr. Rev. 1997, 55, 210-222. [CrossRef] [PubMed]

3. World Health Organization. Iron Deficiency Anaemia: Assessment, Prevention and Control: A Guide for Programme Managers; WHO: Geneva, Switzerland, 2001.

4. Forbes, A.L.; Arnaud, M.; Chichester, C.; Cook, J.; Harrison, B.; Hurrell, R.; Kahn, S.; Morris, E.; Tanner, J.; Whittaker, P. Comparison of in vitro, animal, and clinical determinations of iron bioavailability: International nutritional anemia consultative group task force report on iron bioavailability. Am. J. Clin. Nutr. 1989, 49, 225-238. [PubMed]

5. Hurrell, R.F. Fortification: Overcoming technical and practical barriers. J. Nutr. 2002, 132, 806S-812S. [PubMed]

6. Hoppe, M.; Hulthén, L.; Hallberg, L. The relative bioavailability in humans of elemental iron powders for use in food fortification. Eur. J. Nutr. 2006, 45, 37-44. [CrossRef] [PubMed]

7. Harrison, B.; Pla, G.; Clark, G.; Fritz, J. Selection of iron sources for cereal enrichment. Cereal Chem. 1976, 53, 78-84. 
8. Rohner, F.; Ernst, F.O.; Arnold, M.; Hilbe, M.; Biebinger, R.; Ehrensperger, F.; Pratsinis, S.E.; Langhans, W.; Hurrell, R.F.; Zimmermann, M.B. Synthesis, characterization, and bioavailability in rats of ferric phosphate nanoparticles. J. Nutr. 2007, 137, 614-619. [PubMed]

9. Hurrell, R.F. Bioavailability of iron. Eur. J. Clin. Nutr. 1997, 51, S4-S8. [PubMed]

10. Sharp, P.; Srai, S.K. Molecular mechanisms involved in intestinal iron absorption. World J. Gastroenterol. 2007, 13, 4716-4724. [CrossRef] [PubMed]

11. Reddy, M.B.; Cook, J.D. Assessment of dietary determinants of nonheme-iron absorption in humans and rats. Am. J. Clin. Nutr. 1991, 54, 723-728. [PubMed]

12. Hilty, F.M.; Arnold, M.; Hilbe, M.; Teleki, A.; Knijnenburg, J.T.; Ehrensperger, F.; Hurrell, R.F.; Pratsinis, S.E.; Langhans, W.; Zimmermann, M.B. Iron from nanocompounds containing iron and zinc is highly bioavailable in rats without tissue accumulation. Nat. Nanotechnol. 2010, 5, 374-380. [CrossRef] [PubMed]

13. Glahn, R.P.; Lee, O.A.; Yeung, A.; Goldman, M.I.; Miller, D.D. Caco-2 cell ferritin formation predicts nonradiolabeled food iron availability in an in vitro digestion/caco-2 cell culture model. J. Nutr. 1998, 128, 1555-1561. [PubMed]

14. Glahn, R.P.; Wortley, G.M.; South, P.K.; Miller, D.D. Inhibition of iron uptake by phytic acid, tannic acid, and zncl2: Studies using an in vitro digestion/caco-2 cell model. J. Agric. Food Chem. 2002, 50, 390-395. [CrossRef] [PubMed]

15. Eagling, T.; Wawer, A.A.; Shewry, P.R.; Zhao, F.-J.; Fairweather-Tait, S.J. Iron bioavailability in two commercial cultivars of wheat: Comparison between wholegrain and white flour and the effects of nicotianamine and 2'-deoxymugineic acid on iron uptake into caco-2 cells. J. Agric. Food Chem. 2014, 62, 10320-10325. [CrossRef] [PubMed]

16. Gerloff, K.; Pereira, D.I.; Faria, N.; Boots, A.W.; Kolling, J.; Förster, I.; Albrecht, C.; Powell, J.J.; Schins, R.P. Influence of simulated gastrointestinal conditions on particle-induced cytotoxicity and interleukin-8 regulation in differentiated and undifferentiated caco-2 cells. Nanotoxicology 2013, 7, 353-366. [CrossRef] [PubMed]

17. Swain, J.H.; Newman, S.M.; Hunt, J.R. Bioavailability of elemental iron powders to rats is less than bakery-grade ferrous sulfate and predicted by iron solubility and particle surface area. J. Nutr. 2003, 133, 3546-3552. [PubMed]

18. Wang, X.; Ghio, A.J.; Yang, F.; Dolan, K.G.; Garrick, M.D.; Piantadosi, C.A. Iron uptake and nramp2/dmt1/ dct1 in human bronchial epithelial cells. Am. J. Physiol. Lung Cell Mol. Physiol. 2002, 282, L987-L995. [CrossRef] [PubMed]

19. Tulpule, K.; Robinson, S.R.; Bishop, G.M.; Dringen, R. Uptake of ferrous iron by cultured rat astrocytes. J. Neurosci. Res. 2010, 88, 563-571. [CrossRef] [PubMed]

20. Thompson, B.A.; Sharp, P.A.; Elliott, R.; Fairweather-Tait, S.J. Inhibitory effect of calcium on non-heme iron absorption may be related to translocation of dmt- 1 at the apical membrane of enterocytes. J. Agric. Food Chem. 2010, 58, 8414-8417. [CrossRef] [PubMed]

21. Arredondo, M.; Kloosterman, J.; Núñez, S.; Segovia, F.; Candia, V.; Flores, S.; Le Blanc, S.; Olivares, M.; Pizarro, F. Heme iron uptake by caco-2 cells is a saturable, temperature sensitive and modulated by extracellular ph and potassium. Biol. Trace Element Res. 2008, 125, 109-119. [CrossRef] [PubMed]

22. San Martin, C.D.; Garri, C.; Pizarro, F.; Walter, T.; Theil, E.C.; Núñez, M.T. Caco-2 intestinal epithelial cells absorb soybean ferritin by $\mu 2$ (ap2)-dependent endocytosis. J. Nutr. 2008, 138, 659-666. [PubMed]

23. Kalgaonkar, S.; Lönnerdal, B. Receptor-mediated uptake of ferritin-bound iron by human intestinal caco-2 cells. J. Nutr. Biochem. 2009, 20, 304-311. [CrossRef] [PubMed]

24. Bourseau-Guilmain, E.; Griveau, A.; Benoit, J.-P.; Garcion, E. The importance of the stem cell marker prominin-1/cd133 in the uptake of transferrin and in iron metabolism in human colon cancer caco-2 cells. PLoS ONE 2011, 6, e25515. [CrossRef] [PubMed]

25. Krieger, S.E.; Kim, C.; Zhang, L.; Marjomaki, V.; Bergelson, J.M. Echovirus 1 entry into polarized caco-2 cells depends on dynamin, cholesterol, and cellular factors associated with macropinocytosis. J. Virol. 2013, 87, 8884-8895. [CrossRef] [PubMed]

26. Pereira, D.I.; Mergler, B.I.; Faria, N.; Bruggraber, S.F.; Aslam, M.F.; Poots, L.K.; Prassmayer, L.; Lönnerdal, B.; Brown, A.P.; Powell, J.J. Caco-2 cell acquisition of dietary iron (iii) invokes a nanoparticulate endocytic pathway. PLoS ONE 2013, 8, e81250. [CrossRef] [PubMed] 
27. Latunde-Dada, G.O.; Pereira, D.I.; Tempest, B.; Ilyas, H.; Flynn, A.C.; Aslam, M.F.; Simpson, R.J.; Powell, J.J. A nanoparticulate ferritin-core mimetic is well taken up by hutu 80 duodenal cells and its absorption in mice is regulated by body iron. J. Nutr. 2014, 144, 1896-1902. [CrossRef] [PubMed]

28. Livak, K.J.; Schmittgen, T.D. Analysis of relative gene expression data using real-time quantitative pcr and the 2-(delta delta $\mathrm{c}(\mathrm{t}))$ method. Methods 2001, 25, 402-408. [CrossRef] [PubMed]

29. Motzok, I.; Pennell, M.; Davies, M.; Ross, H. Effect of particle size on the biological availability of reduced iron. J. Assoc. Off. Anal. Chem. 1975, 58, 99-103. [PubMed]

30. Lynch, S.R. The impact of iron fortification on nutritional anaemia. Best Pract. Res. Clin. Haematol. 2005, 18, 333-346. [CrossRef] [PubMed]

31. Fidler, M.C.; Walczyk, T.; Davidsson, L.; Zeder, C.; Sakaguchi, N.; Juneja, L.R.; Hurrell, R.F. A micronised, dispersible ferric pyrophosphate with high relative bioavailability in man. Br. J. Nutr. 2004, 91, 107-112. [CrossRef] [PubMed]

32. Wegmüller, R.; Camara, F.; Zimmermann, M.B.; Adou, P.; Hurrell, R.F. Salt dual-fortified with iodine and micronized ground ferric pyrophosphate affects iron status but not hemoglobin in children in cote d'ivoire. J. Nutr. 2006, 136, 1814-1820. [PubMed]

33. Moretti, D.; Zimmermann, M.B.; Muthayya, S.; Thankachan, P.; Lee, T.-C.; Kurpad, A.V.; Hurrell, R.F. Extruded rice fortified with micronized ground ferric pyrophosphate reduces iron deficiency in indian schoolchildren: A double-blind randomized controlled trial. Am. J. Clin. Nutr. 2006, 84, 822-829. [PubMed]

34. Roe, M.A.; Collings, R.; Hoogewerff, J.; Fairweather-Tait, S.J. Relative bioavailability of micronized, dispersible ferric pyrophosphate added to an apple juice drink. Eur. J. Nutr. 2009, 48, 115-119. [CrossRef] [PubMed]

35. Nel, A.; Xia, T.; Mädler, L.; Li, N. Toxic potential of materials at the nanolevel. Science 2006, 311, 622-627. [CrossRef] [PubMed]

36. Des Rieux, A.; Ragnarsson, E.G.; Gullberg, E.; Préat, V.; Schneider, Y.-J.; Artursson, P. Transport of nanoparticles across an in vitro model of the human intestinal follicle associated epithelium. Eur. J. Pharm. Sci. 2005, 25, 455-465. [CrossRef] [PubMed]

37. Abbott, L.C.; Maynard, A.D. Exposure assessment approaches for engineered nanomaterials. Risk Anal. 2010, 30, 1634-1644. [CrossRef] [PubMed]

38. Fröhlich, E. The role of surface charge in cellular uptake and cytotoxicity of medical nanoparticles. Int. J. Nanomed. 2012, 7, 5577-5591. [CrossRef] [PubMed]

39. Wawer, A.A.; Sharp, P.A.; Perez-Moral, N.; Fairweather-Tait, S.J. Evidence for an enhancing effect of alginate on iron availability in caco-2 cells. J. Agric. Food Chem. 2012, 60, 11318-11322. [CrossRef] [PubMed]

40. Au, A.P.; Reddy, M.B. Caco-2 cells can be used to assess human iron bioavailability from a semipurified meal. J. Nutr. 2000, 130, 1329-1334. [PubMed]

41. Yun, S.; Habicht, J.-P.; Miller, D.D.; Glahn, R.P. An in vitro digestion/caco-2 cell culture system accurately predicts the effects of ascorbic acid and polyphenolic compounds on iron bioavailability in humans. J. Nutr. 2004, 134, 2717-2721. [PubMed]

42. Lynch, B.; Campbell, L. A comparison of physical properties, screening procedures and a human efficacy trial for predicting the bioavailability of commercial elemental iron powders used for food fortification. Int. J. Vitam. Nutr. Res. 2007, 77, 107-124. [CrossRef] [PubMed]

43. Arredondo, M.; Salvat, V.; Pizarro, F.; Olivares, M. Smaller iron particle size improves bioavailability of hydrogen-reduced iron-fortified bread. Nutr. Res. 2006, 26, 235-239. [CrossRef]

44. He, W.-L.; Feng, Y.; Li, X.-L.; Yang, X.-E. Comparison of iron uptake from reduced iron powder and feso4 using the caco-2 cell model: Effects of ascorbic acid, phytic acid, and ph. J. Agric. Food Chem. 2008, 56, 2637-2642. [CrossRef] [PubMed]

45. Wortley, G.; Leusner, S.; Good, C.; Gugger, E.; Glahn, R. Iron availability of a fortified processed wheat cereal: A comparison of fourteen iron forms using an in vitro digestion/human colonic adenocarcinoma (caco-2) cell model. Br. J. Nutr. 2005, 93, 65-71. [CrossRef] [PubMed]

46. Yeung, C.K.; Miller, D.D.; Cheng, Z.; Glahn, R.E. Bioavailability of elemental iron powders in bread assessed with an in vitro digestion/caco-2 cell culture model. J. Food Sci. 2005, 70, S199-S203. [CrossRef]

47. Conrad, M.E.; Umbreit, J.N. Iron absorption and transport-An update. Am. J. Hematol. 2000, 64, $287-298$. [CrossRef] 
48. Kararli, T.T. Comparison of the gastrointestinal anatomy, physiology, and biochemistry of humans and commonly used laboratory animals. Biopharm. Drug Dispos. 1995, 16, 351-380. [CrossRef] [PubMed]

49. McConnell, E.L.; Basit, A.W.; Murdan, S. Measurements of rat and mouse gastrointestinal ph, fluid and lymphoid tissue, and implications for in-vivo experiments. J. Pharm. Pharmacol. 2008, 60, 63-70. [CrossRef] [PubMed]

50. Des Rieux, A.; Fievez, V.; Théate, I.; Mast, J.; Préat, V.; Schneider, Y.-J. An improved in vitro model of human intestinal follicle-associated epithelium to study nanoparticle transport by m cells. Eur. J. Pharm. Sci. 2007, 30, 380-391. [CrossRef] [PubMed]

51. Jahn, M.R.; Nawroth, T.; Fütterer, S.; Wolfrum, U.; Kolb, U.; Langguth, P. Iron oxide/hydroxide nanoparticles with negatively charged shells show increased uptake in caco-2 cells. Mol. Pharmacol. 2012, 9, 1628-1637. [CrossRef] [PubMed]

52. Antileo, E.; Garri, C.; Tapia, V.; Muñoz, J.P.; Chiong, M.; Nualart, F.; Lavandero, S.; Fernández, J.; Núñez, M.T. Endocytic pathway of exogenous iron-loaded ferritin in intestinal epithelial (Caco-2) cells. Am. J. Physiol.-Gastrointest. Liver Physiol. 2013, 304, G655-G661. [CrossRef] [PubMed]

53. Mahler, G.J.; Shuler, M.L.; Glahn, R.P. Characterization of caco-2 and ht29-mtx cocultures in an in vitro digestion/cell culture model used to predict iron bioavailability. J. Nutr. Biochem. 2009, 20, 494-502. [CrossRef] [PubMed]

54. Mahler, G.J.; Esch, M.B.; Tako, E.; Southard, T.L.; Archer, S.D.; Glahn, R.P.; Shuler, M.L. Oral exposure to polystyrene nanoparticles affects iron absorption. Nat. Nanotechnol. 2012, 7, 264-271. [CrossRef] [PubMed]

55. World Health Organization; Allen, L.H.; De Benoist, B.; Dary, O.; Hurrell, R. Guidelines on Food Fortification with Micronutrients; World Health Organization: Geneva, Switzerland, 2006.

(C) 2017 by the authors. Licensee MDPI, Basel, Switzerland. This article is an open access article distributed under the terms and conditions of the Creative Commons Attribution (CC BY) license (http:/ / creativecommons.org/licenses/by/4.0/). 